DOI: 10.20472/IAC.2017.029.023

JASON MITCHELL

University of Nevada, Las Vegas, United States

\title{
LEGAL REALITY V. LEGAL THEORY: THE UNINTENDED CONSEQUENCES AND REAL WORLD IMPLICATIONS OF U.S. FOREIGN POLICY AND LEGAL THEORY.
}

\begin{abstract}
:
One of the many policies commonly referred to as the Bush Doctrine is the right to preemptively attack foreign regimes that represent a threat to the security of the United States (US). Moreover, the U.S. may use unilateral military action. This policy initiative stems from the Global War on Terror (GWT). The Bush Doctrine and the GWT have necessitated the reconsideration of the legal treatment of non-state actors under International Law. It is to this policy I refer when stating the "Bush Doctrine." It is upon this policy that I focus in this paper.

The Bush Doctrine violates international law; nevertheless, the doctrine itself is not a radical departure from US foreign policy. It is the logical conclusion of a deliberate statecraft best articulated by Henry R. Luce who famously argued: the US should “... accept wholeheartedly our duty to exert upon the world the full impact of our influence for such purposes as we see fit and by such means as we see fit." Toward this end, the US has influenced and manipulated geo-politics for decades. At the top of the list of strategic interests is that the US become and remain the world's sole superpower. Any challenge, real or perceived, to that status is deemed a threat and is dealt with accordingly. The Bush Doctrine has also created a situation where non-state actors can be denied any and all legal protections under international law.

In this paper I analyze the normative, legal, and strategic justifications for preventive military actions, as well as the treatment of non-state actors; I also demonstrate the Bush doctrine undermines emerging notions of international normative values, and well-established values of the US. As a legal argument the Bush doctrine violates international law; as a strategy it undermines the US's goals of peace and prosperity. Despite its rhetoric, the US is a de facto rogue state interested only in pursuing its immediate interests. I conclude the US must embrace the rule of law, extend legal protection to non-state actors, engage the international community, and commit to supporting and strengthening existing international institutions, rather than subverting them. In support of this conclusion I introduce a new descriptive legal theory that reconciles the debate between natural law and legal positivism. Through this new descriptive legal theory society may gain a better understanding for the need for education and tolerance across and among both nations and nation-states.
\end{abstract}

\section{Keywords:}

International Law; International Relations; Terrorism; Legal Theory; Philosophy; Political Theory; Moral Theory.

JEL Classification: F59 